\title{
The Influence of Scramble Learning Models and Motivation Learning on the Results of Citizension Education Class V SD Students State 101766 Bandar Setia
}

\author{
Dewi Lestari ${ }^{1}$, Reh Bungana ${ }^{2}$, Siman $^{3}$ \\ ${ }^{1}$ Postgraduate Program in Universitas Negeri Medan, Indonesia \\ ${ }^{2,3}$ Universitas Negeri Medan, Indonesia \\ dewi.lestari632@yahoo.com
}

\section{Abstract}

Teachers have a duty to encourage, guide and provide learning facilities to achieve goals. Teachers have a responsibility to see everything that happens in the classroom to help student development. Teachers must be able to carry out their duties properly by first having to understand carefully the matters relating to the teaching and learning process, because the success of the learning process is supported by the ability of the teacher to develop and generate activeness and students in the learning process. The research method used is the Quasi Experiment (Quasi Experimental Method) with the research design as the basisfor the implementation of the research is to distinguish the influence of the Inquiry method and the effect of conventional methods on learning outcomes of Citizenship Education in terms of high learning motivation and low learning motivation where the treatment class is class Va student and Vb class. The following is presented sequentially descriptive data regarding: (1) Civics learning outcomes students are taught using scramble learning model, (2) Civics student learning outcomes are taught using the expository model, (3) Civics student learning outcomes have high learning motivation, (4) Civics student learning outcomes have motivation to learn low, (5)Civics learning outcomes of students who have high learning motivation are taught with the Scramble learning model, (6) Civics learning outcomes of students who have low learning motivation are taught with the Scramble learning model, (7) Civics learning outcomes of students who have high learning motivation are taught using the expository learning model, (8) Civics learning outcomes of students who have low learning motivation are taught using the expository learning model.
Keywords scramble learning; motivation learning; citizension education

\section{Introduction}

Education is an important means of improving the quality of human resources (HR) in ensuring the sustainability of a nation's development because education is the main instrument of human resource development. Human resource development is not only based on the quality of a person in mastering a particular skill, but even more so that he can become a desirable person. Humans and education cannot be separated, because education is the key to a human future that is equipped with a mind. Education has an important role in ensuring the development and survival of a nation, because education is a vehicle for enhancing and developing competent and quality human resources. 
To form humans to be reliable, knowledge is needed that plays a role in shaping one's character and noble character. This is based on the Regulation of the Minister of National Education Number 22 of 2006 concerning the subject of Citizenship Education (Civics). In accordance with the Regulation of the Minister of National Education Number 22 of 2006 that Citizenship Education (Civics) is a subject that focuses on the formation of citizens who understand and are able to exercise their rights and obligations to become smart, skilled, and character Indonesian citizens mandated by Pancasila and UUD 1945. For that Citizenship Education is a subject that must be studied at every level of education.

According to Ahmadi (2003) the low quality of education is caused by several factors, namely (1) the education funding factor is still small, (2) the inadequate educational facilities and infrastructure, (3) the curriculum factor that does not support improving the quality of education because it is still too centralized and (4) education management, including the large factor of government bureaucratic interference and the low quality of teachers. Of the five factors causing the low quality of education stated by Ahmadi above, the teacher factor is a very decisive factor, because it is the teacher who plays a direct role in the learning process, namely in the delivery of learning material to students and influencing students to be active in the learning process.

Teachers have a duty to encourage, guide and provide learning facilities to achieve goals. Teachers have a responsibility to see everything that happens in the classroom to help student development. Teachers must be able to carry out their duties properly by first having to understand carefully the matters relating to the teaching and learning process, because the success of the learning process is supported by the ability of the teacher to develop and generate activeness and students in the learning process.

\section{Review of Literatures}

\subsection{The Nature of Civics Learning Outcomes}

Citizenship Education (Civics) has a very important role in ensuring the development and survival of an Indonesian state government and advancing general welfare (Simanjuntak, 2020). All activities carried out by humans in an effort to improve themselves or in other words positive human activities are called learning. Learning is a routine activity carried out by humans to live their lives.

According to Slameto (2010: 2) "Learning is a business process carried out by a person to obtain a whole new change in behavior, as a result of his own experience in interaction with his environment". Then according to Muhibbinsyah (2010: 87) argues that "Learning is an activity that has a process and is a very fundamental element in the implementation of every type and level of education. This means that the success or failure of achieving educational goals is very dependent on the learning process experienced by students, both when they are at school or in their own home or family environment. According to Nidawati (2013: 13-28) argues learning is an activity that is in process and is a very fundamental element in any type and level of education. Furthermore Munawaroh (2015: 263-173) also has an opinionlearning has the potential to enhance learning through the process of writing and thinking about learning experiences, is personal and can be used for self-reflection. Learning is an activity for everyone. Learning is often defined as a process of change that can be in the form of developing knowledge, attitudes, skills and students are expected to be able to solve problems or demands in life. Therefore, a person is said to learn when a process occurs in that person which results in a change in behavior. Activities and efforts to achieve behavioral change are a learning process. 


\subsection{Scramble Learning Model}

According to Ariyanto (2016: 134-140) states that the scramble learning model is learning in groups by matching the provided question cards and answer cards. Furthermore, Ahmad (2013: 7-14) suggests that the scramble learning model has 2 steps, namely Scramble is one type of cooperative learning that is presented in the form of a card as follows:

a. The teacher presents the material according to the basic competence to be achieved.

b. Distributing student worksheet (LKS).

According to Istarani (2011: 184) suggests the understanding of the Scramble learning model, namely:

Learning model Scramble presenting teaching material through the submission of questions or statements that are incomplete, so that learning participants are called on to complete the statement which is an application of the use of the Scramble learning model. So, in using the Scramble learning model, there are two very important components, namely incomplete questions or statements, namely students are asked to complete the statement so that it is perfect, and the second is to prepare words or sentences that can complement the question or statement so that perfect. This is how teaching materials are delivered to students using the Scramble learning model.

According to Kokom Komalasari (2012: 2) argues that "scramble learning model is a learning model that invites students to creatively seek answers to a question or pair of concepts by arranging randomly arranged letters to form an answer or concept pair" .

According to Kiran Kumar (2010) argues that "this scramble technique is very suitable to be used in learning by using randomly generated question cards which can make students think creatively to compose a perfect randomly arranged question card".

Meanwhile, according to Suyatno (2012: 2) argues that "scramble learning model is a learning method that uses question cards and answer cards that are paired or sorted into a logical sequence. So that students are required to think creatively in learning in the classroom, to be able to sort the words in the answer key into logical words.

Based on the definitions that have been described, it can be concluded that the scramble learning model is a learning model that provides randomized numbered question cards and answer cards that can make it easier for students to find answers and encourage students to learn to work on these questions, and can encourage students to solve problem quickly.

\subsection{Expository Model}

The expository learning model is a model that is often used by teachers in the field. This can be seen by the dominating use of this model in teaching and learning activities. And that is one of the most dominant characteristics of this model. Because in reality this model is the same as the lecture model which makes the teacher a source of information. Seeing this, the researcher intends to compare the Scramble learning model with this model.

The expository learning model is a direct learning model carried out by the teacher. Meanwhile, students are not required to find material. So that this model can be said to be excellent for teachers, because it has a method that is very well known and familiar to teachers, namely the lecture method. Where in the use of the lecture method, students are considered as white paper, clean and holy. The teacher is in charge of filling in the blanks of the white paper with various knowledge. It's like filling an empty bucket with liters of water. 
According to Sanjaya (2010: 179) "Expository is a learning model that emphasizes the verbal delivery process from a teacher to a group of students with the intention that students can master the subject matter optimally. So this model is a form of teachercentered learning. In this model the teacher plays a very dominant role by teaching the material structurally in the hope that students can master the material.

Meanwhile, according to Roy Killen (in Sanjaya, 2010: 179) implements an expository model with direct learning by the teacher so that it emphasizes the speaking process and is better known as chalk and talk.

From the explanation that has been described, it can be concluded that expository learning is learning that is directly carried out by the teacher, while students are not required to find the material. This is because expository learning is teacher centered learning or active teachers while students only listen to information (passive).

\subsection{Learning Motivation}

If viewed from the origin of the word, namely motive, motivation can be defined as anything that encourages someone to carry out activities with anything that encourages someone to do certain activities to achieve certain goals. Motivation itself is the whole driving force both inside and outside by creating a certain series of efforts that ensure continuity and provide direction to activities so that the desired goals can be achieved. The statement is supported by Purwanto (2011: 71) which states that "motivation is a conscious effort to influence a person's behavior so that he moves his heart to act to do something so as to achieve certain results or goals".

Motivation arises when it is driven by someone's need for something. Likewise with learning, if someone has a high level of need for learning achievement, the student will try hard to achieve his target even though it is full of challenges.

According to Hasan Afzal (2010) states that "student motivation is one of the requirements for students to excel in the learning process". Meanwhile, according to Nina Isnawati (2012: 79) "motivation is encouragement that comes from students. Motivation also plays an important role in the learning process.

According to Sadirman (2010: 75) states that "motivation is the psychic driving force that comes from within a person to be able to carry out learning activities and increase skills and experiences".

\section{Research Methods}

This research was conducted in SD Negeri 101766 Bandar Setia. The time of the research was carried out in even Semester. Research time research refers to the syllabus of Civics subjects.

The population of this study were all fifth grade students of SD Negeri 101766 Bandar Setia which consisted of 2 classes totaling 70 students, including class $\mathrm{Va}$ consisting of 35 students and class $\mathrm{Vb}$ consisting of 35 students.

Table 1. Research Population

\begin{tabular}{|c|c|c|}
\hline No. & Class & $\begin{array}{c}\text { The Number of } \\
\text { Students }\end{array}$ \\
\hline 1 & $\mathrm{Va}$ & 22 \\
\hline 2 & $\mathrm{Vb}$ & 22 \\
\hline \multicolumn{2}{|c|}{ TOTAL } & $\mathbf{4 4}$ \\
\hline
\end{tabular}


Considering that this research carried out treatment and the number of classes was only 2 (two classes), the research sample was determined using the purposive random sampling technique, namely from class $\mathrm{Va}$ and class $\mathrm{Vb}$, then the determination for the Scramble Learning Model class and the Expository class was carried out by lottery.

In class $\mathrm{Va}$ there were 22 students while in class $\mathrm{Vb}$ there were 22 students. The total sample size is 44 students. The research subject was taken based on the level of learning motivation that students have in each class. From each class each sample will be taken, namely students who have high learning motivation and students who have low learning motivation.

The research method used is the Quasi Experiment (Quasi Experimental Method) with the research design as the basis for the implementation of the research is to distinguish the influence of the Inquiry method and the effect of conventional methods on learning outcomes of Citizenship Education in terms of high learning motivation and low learning motivation where the treatment class is class $\mathrm{Va}$ students. and $\mathrm{Vb}$ class.

Before being given the treatment, the researcher especially provided motivation to class $\mathrm{Va}$ as many as 22 students and class $\mathrm{Vb}$ as many as 22 students whose aim was to make students enthusiastic in the learning process. The treatment was carried out in two experimental classes, namely the class using the scramble learning model and the class using the expository model. The determination of the experimental class was carried out by lottery. Before the teacher taught, they were first given an explanation of the implementation of the treatment they would do. Striving for the same learning environment conditions. This treatment is attempted for 4 (four) meetings, after completion of all topics and a post-test. Then the teacher prepares the subject matter to be given, determines the learning model, resources and teaching aids used. The teacher determines the activities to be carried out in the classroom according to the learning model that will be applied (experimented). Presentation of subject matter for students with the Scramble Learning Model includes: (1) presenting the material or problem; (2) Preparing questions; (3) Give time to work on questions; (4) collect and analyze data; and (6) Making conclusions. While the presentation of lesson material for students using conventional methods includes: (1) preparation; (2) delivery of material; (3) Linking material; (4) To conclude; (5) Applying; (2) Preparing questions; (3) Give time to work on questions; (4) collect and analyze data; and (6) Making conclusions. While the presentation of lesson material for students using conventional methods includes: (1) preparation; (2) delivery of material; (3) Linking material; (4) To conclude; (5) Applying; (2) Preparing questions; (3) Give time to work on questions; (4) collect and analyze data; and (6) Making conclusions. While the presentation of lesson material for students using conventional methods includes: (1) preparation; (2) delivery of material; (3) Linking material; (4) To conclude; (5) Applying.

\section{Discussion}

The following is presented sequentially descriptive data regarding: (1) Civics learning outcomes students are taught using scramble learning model, (2) Civics student learning outcomes are taught using the expository model, (3) Civics student learning outcomes have high learning motivation, (4) Civics student learning outcomes have motivation to learn low, (5)Civics learning outcomes of students who have high learning motivation are taught with the Scramble learning model, (6) Civics learning outcomes of students who have low learning motivation are taught with the Scramble learning model, (7) Civics learning outcomes of students who have high learning motivation are taught 
using the expository learning model, (8) Civics learning outcomes of students who have low learning motivation are taught using the expository learning model.

Table 2. Description of Student Civics Learning Outcomes Data Taught by Using Scramble Learning Model

\begin{tabular}{ccc}
\hline Interval Class & Absolute Frequency & Relative Frequency (\%) \\
\hline $65-71$ & 3 & 13.6 \\
$72-78$ & 2 & 9,1 \\
$79-85$ & 7 & 31.8 \\
$86-92$ & 6 & 27.3 \\
$93-100$ & 4 & 18.2 \\
\hline Total & 22 & 100 \\
\hline
\end{tabular}

Based on the data in Table 2, it can be explained that most of the students were on average 84.32 in the $79-85$ interval class with a percentage of $31.8 \%$, then $22.7 \%$ were below the class average score and $45.5 \%$ above the class average score. Furthermore, the histogram graph of the Civics learning outcomes of students who are taught usingscramble learning model presented in Figure 1.

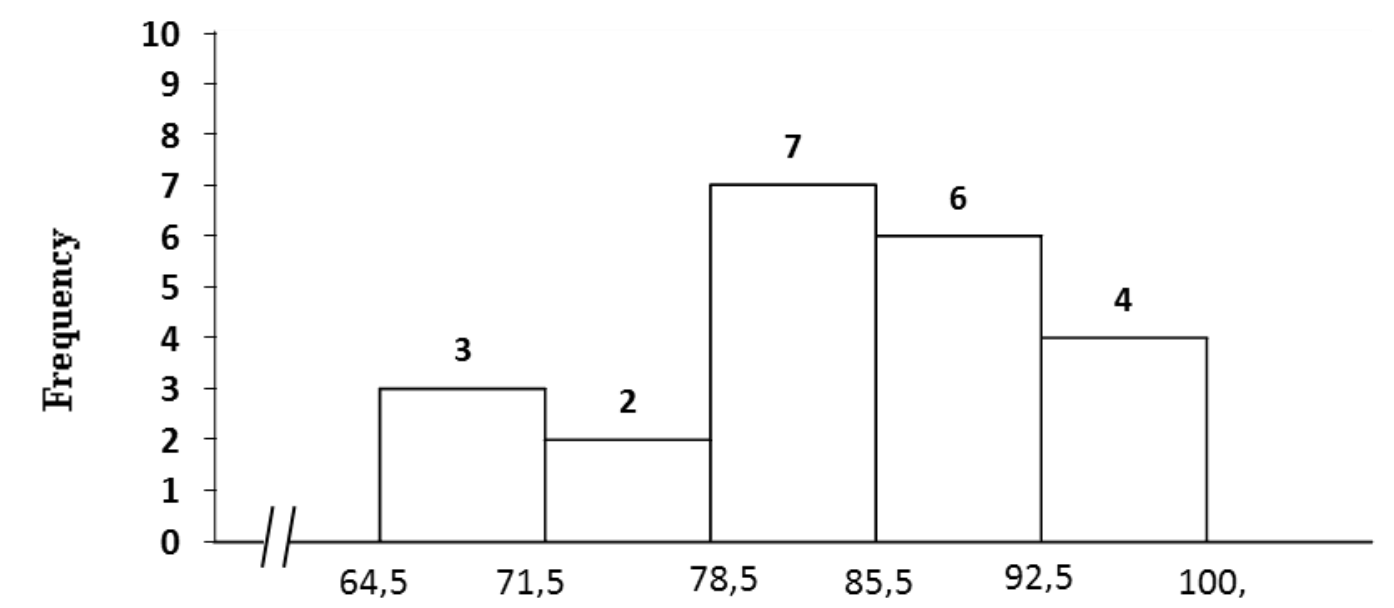

Figure 1. Histograms of Student Civics Learning Results Taught Using Scramble Learning Model

Table 3. Description of Student Civics Learning Outcomes Data Taught by Using Expository Learning Model

\begin{tabular}{ccc}
\hline Interval Class & Absolute Frequency & Relative Frequency \\
\hline $50-58$ & 4 & 18.2 \\
$59-67$ & 3 & 13.6 \\
$68-76$ & 9 & 40.9 \\
$77-85$ & 4 & 18.2 \\
$86-95$ & 2 & 9,1 \\
\hline total & 22 & 100 \\
\hline
\end{tabular}




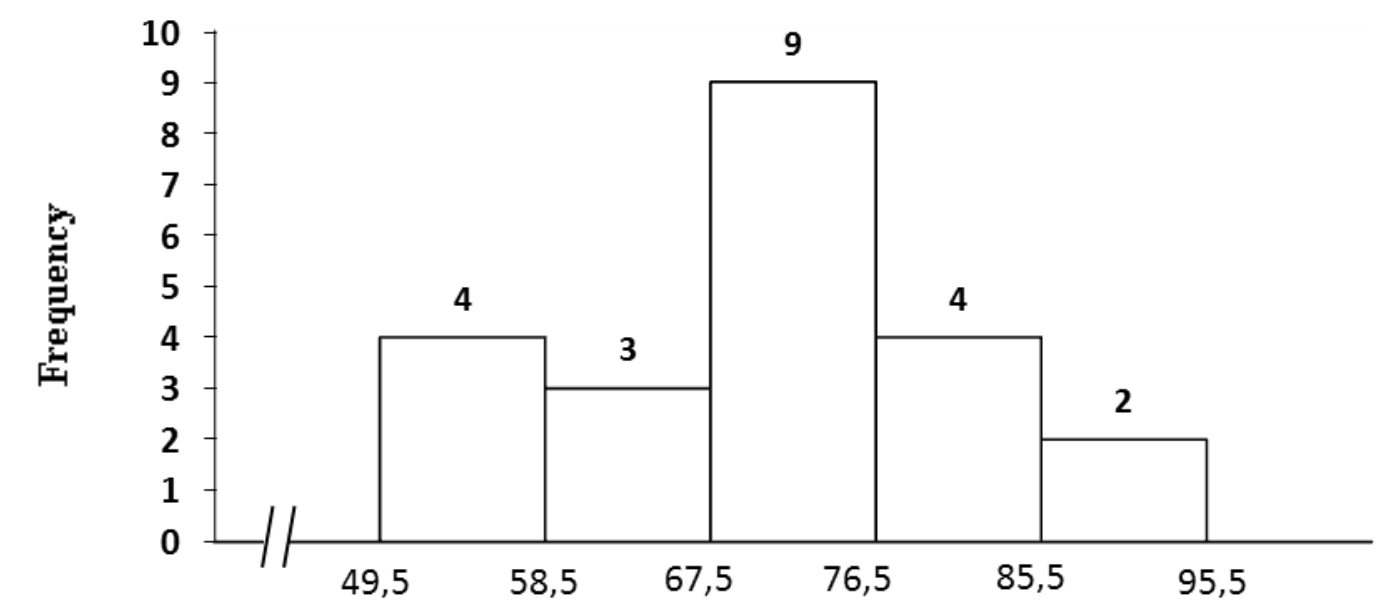

Figure 2. The Histogram of Civics Learning Outcomes of Students who are Taught Using Expository Learning Model

Table 4. Description of Student Civics Learning Outcomes Data Have High Learning Motivation

\begin{tabular}{ccc}
\hline Interval Class & Absolute Frequency & Relative Frequency \\
\hline $55-63$ & 1 & 4,3 \\
$64-72$ & 4 & 17.4 \\
$73-81$ & 8 & 34.8 \\
$82-90$ & 7 & 30.4 \\
$91-100$ & 3 & 13.0 \\
\hline total & 23 & 100 \\
\hline
\end{tabular}

Based on the data in Table 4 it can be explained that most of the students' scores were between the average score of 81.30 in the 73-81 interval class with a percentage of $34.8 \%$, then $21.7 \%$ was below the class average score and 43.4 . \% above the class average score. Furthermore, the histogram graph of students' Civics learning outcomeshave high learning motivationpresented in Figure 3.

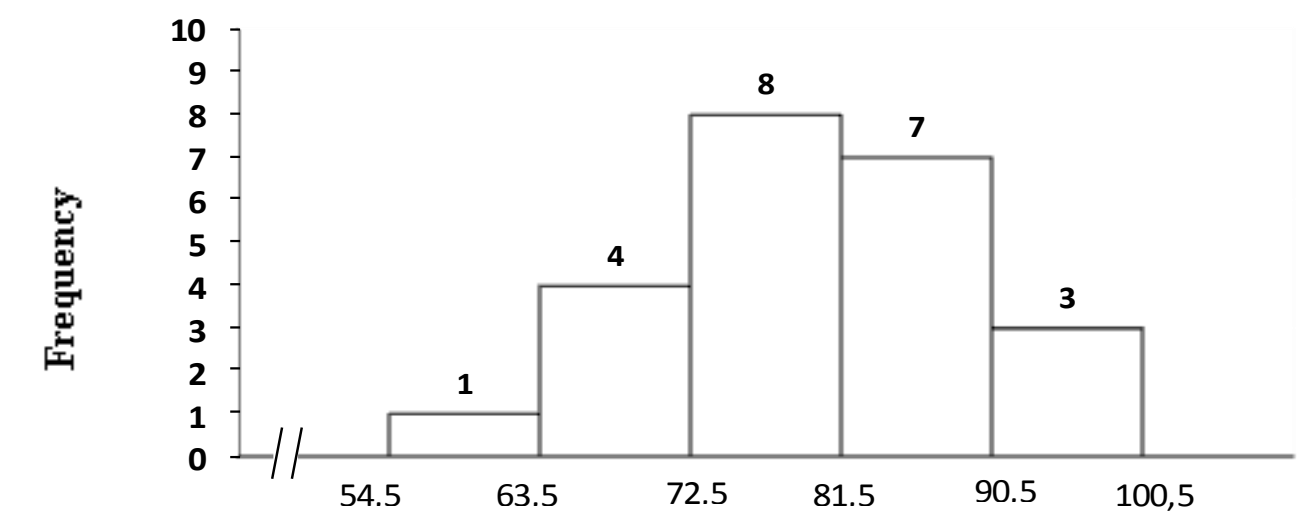

Figure 3. Histogram Data of Civics Student Learning Outcomes have High Learning Motivation 
Table 5. Data Description Result Learning Civics Students who have Learning Motivation Low

\begin{tabular}{ccc}
\hline Interval Class & Absolute Frequency & Relative Frequency \\
\hline $50-58$ & 3 & 14.3 \\
$59-67$ & 4 & 19.0 \\
$68-76$ & 6 & 28.6 \\
$77-85$ & 4 & 19.0 \\
$86-95$ & 4 & 19.0 \\
\hline total & 21 & 100 \\
\hline
\end{tabular}

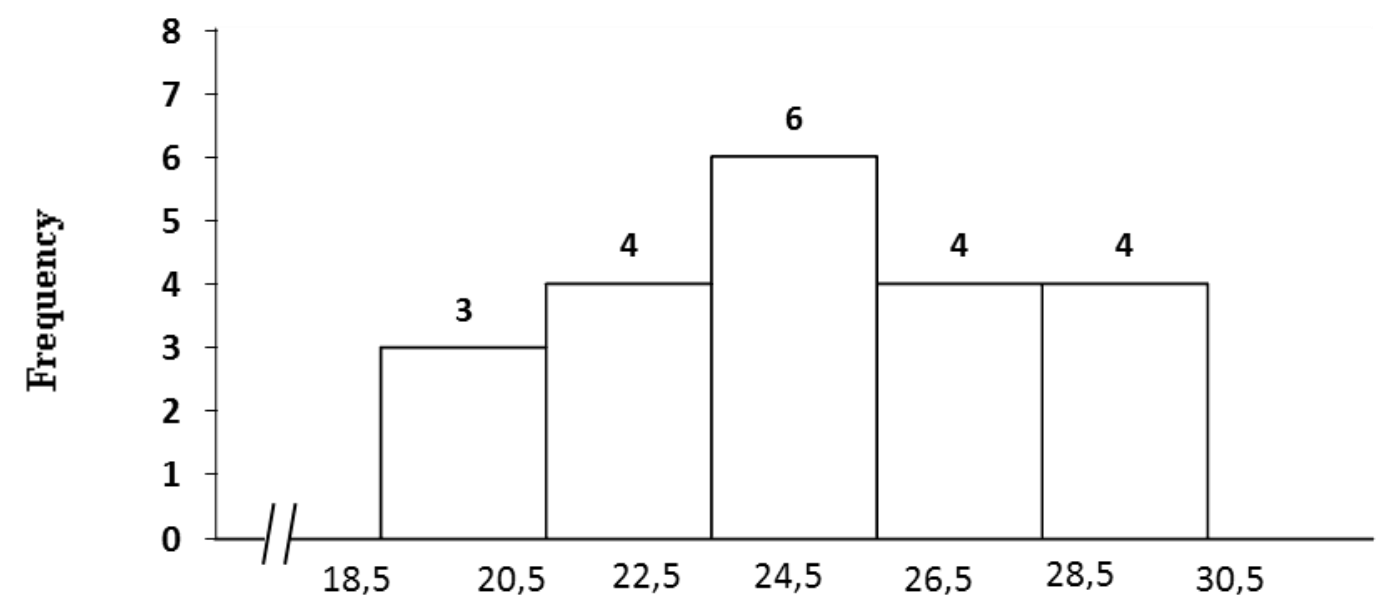

Figure 4. Histogram Data Result Learning Civics Students who have Learning Motivation Low

Table 6. Result Data Description Learning Civics Students Who Have High Learning Motivation Taught Using Scramble Learning Model

\begin{tabular}{ccc}
\hline Interval Class & Absolute Frequency & $\begin{array}{c}\text { Relative } \\
\text { Frequency }\end{array}$ \\
\hline $70-75$ & 2 & 16.7 \\
$76-81$ & 4 & 33.3 \\
$82-87$ & 1 & 8.3 \\
$88-93$ & 3 & 25.0 \\
$94-100$ & 2 & 16.7 \\
\hline total & 12 & 100 \\
\hline
\end{tabular}




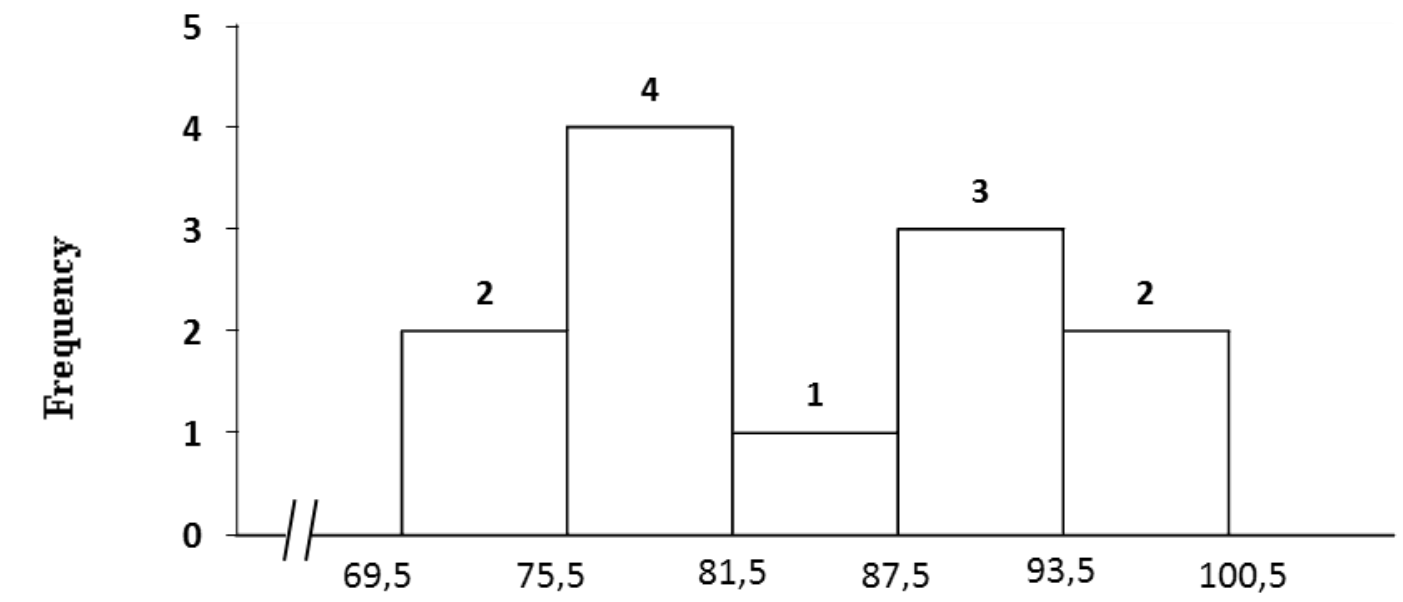

Figure 5. Result Histogram Learning Civics Students who have High Learning Motivation are Taught Using the Scramble Learning Model

Table 7. Description of Learning Outcomes Data Civics Students who have Low Learning Motivation Taught Using Scramble Learning Model

\begin{tabular}{ccc}
\hline Interval Class & $\begin{array}{c}\text { Absolute } \\
\text { Frequency }\end{array}$ & Relative Frequency \\
\hline $65-72$ & 1 & 10.0 \\
$73-80$ & 2 & 20.0 \\
$81-88$ & 4 & 40.0 \\
$89-96$ & 3 & 30.0 \\
\hline total & 10 & 100 \\
\hline
\end{tabular}

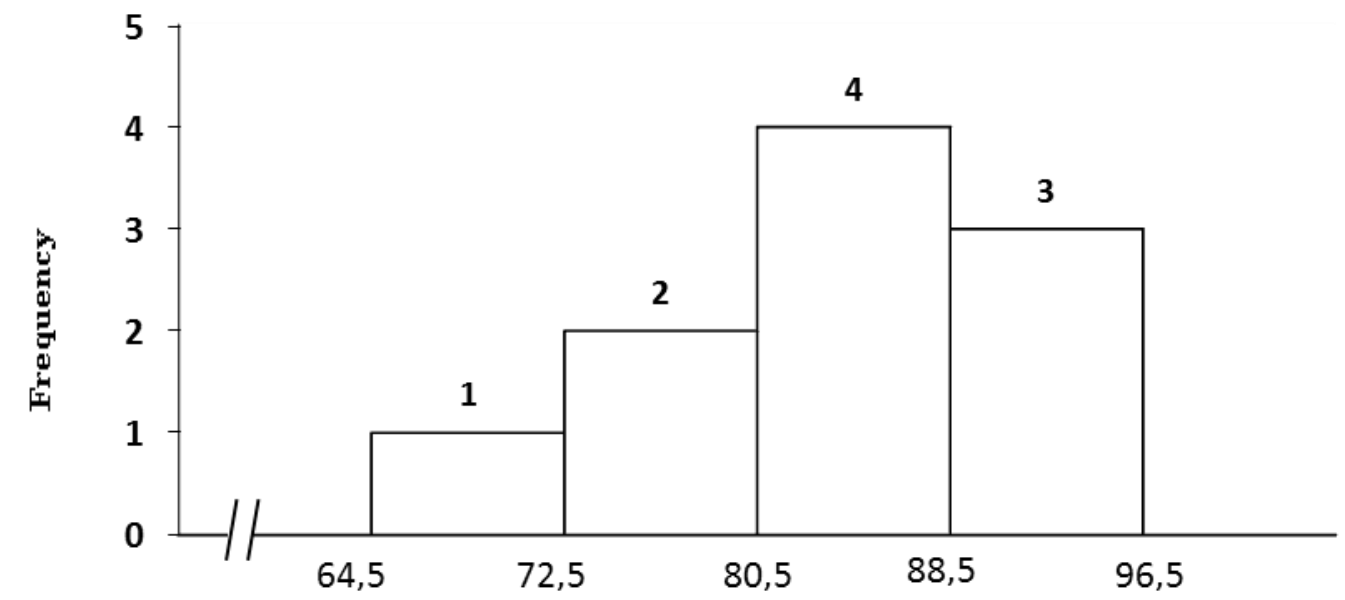

Figure 6. Histogram of Learning Outcomes Civics Students who have Low Learning Motivation are Taught Using the Scramble Learning Model 
Table 8. Description of Learning Outcomes Data Civics Students who have High Learning Motivation are Taught with Expository Learning Models

\begin{tabular}{ccc}
\hline Interval Class & Absolute Frequency & Relative Frequency \\
\hline $55-64$ & 1 & 9,1 \\
$65-74$ & 5 & 45.5 \\
$75-84$ & 3 & 27.3 \\
$85-95$ & 2 & 18.2 \\
\hline total & 11 & 100 \\
\hline
\end{tabular}

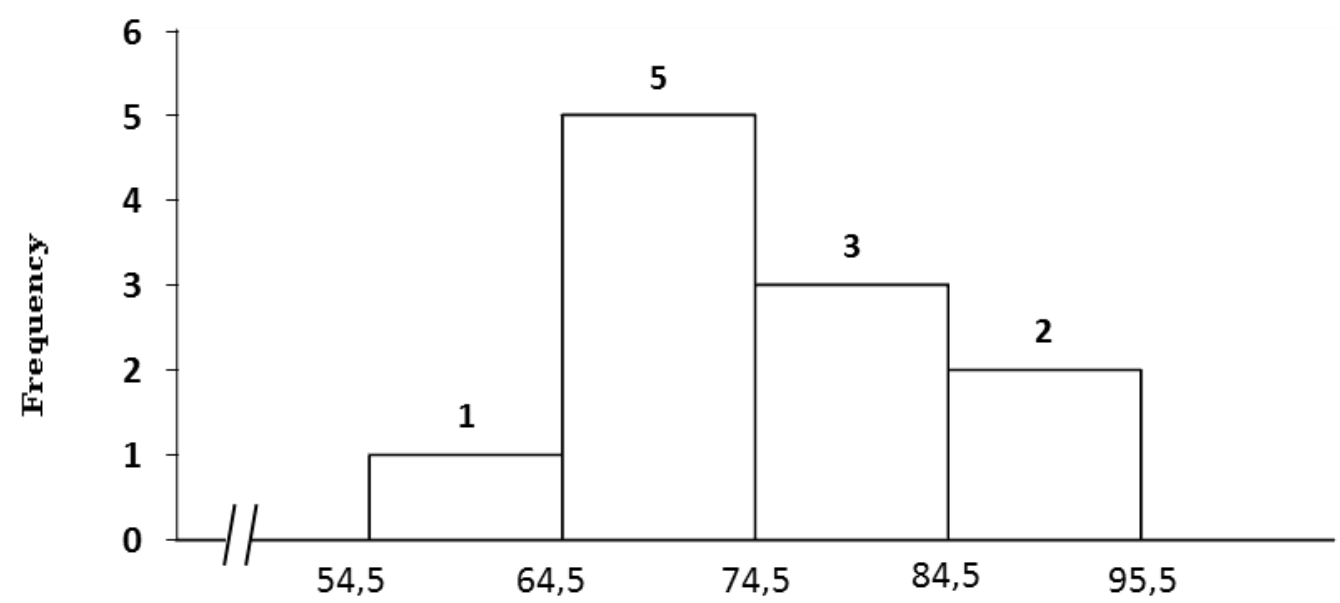

Figure 7. Histogram of Learning Outcomes Civics Students who have High Learning Motivation are Taught Using the Expository Learning Model

Table 9. Description of Learning Outcomes Data Civics Students who have Low Learning Motivation Taught by Expository Learning Model

\begin{tabular}{ccc}
\hline Interval Class & Absolute Frequency & Relative Frequency \\
\hline $50-57$ & 3 & 27.3 \\
$58-65$ & 3 & 27.3 \\
$66-73$ & 4 & 36.4 \\
$74-81$ & 1 & 9,1 \\
\hline total & 11 & 100 \\
\hline
\end{tabular}




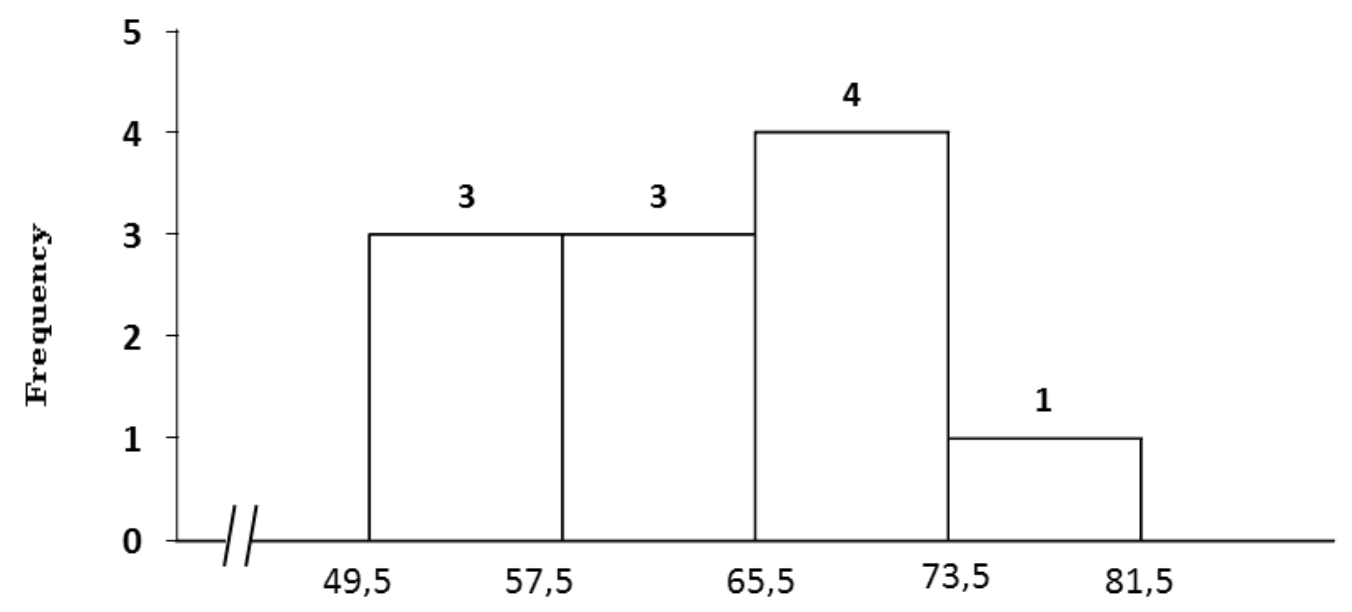

Figure 8. Histogram of Learning Outcomes Civics Students who have Low Learning Motivation Are Taught Using the Expository Learning Model

Table 10. Recapitulation of Data Normality Test Results

\begin{tabular}{ccccc}
\hline $\begin{array}{c}\text { Group } \\
\text { Sample }\end{array}$ & $\begin{array}{c}\text { total } \\
\text { Sample }\end{array}$ & Lhitung & Ltabel & Conclusion \\
\hline I & 22 & 0.089 & 0.189 & Normal \\
II & 22 & 0.113 & 0.189 & Normal \\
III & 23 & 0.114 & 0.185 & Normal \\
IV & 21 & 0.118 & 0.193 & Normal \\
V & 12 & 0.116 & 0.242 & Normal \\
VI & 10 & 0.159 & 0.258 & Normal \\
VII & 11 & 0.143 & 0.249 & Normal \\
VIII & 11 & 0.161 & 0.249 & Normal \\
\hline
\end{tabular}

Table 11. Summary of Homogeneity Test Analys is of Civics Learning Outcomes Teaching Students Using Scramble Learning Model and the Expository Model

\begin{tabular}{llllccc}
\hline \multicolumn{3}{c}{ Sample Group } & & $\mathbf{F}_{\text {hitung }}$ & $\mathbf{F}_{\text {tabel }}$ & Information \\
\hline Civics & learning outcomes students are taught & 1.77 & 2.08 & Homogeneou \\
using & Scramble learning model and the & & & $\mathrm{s}$ \\
expository model & & & & & \\
\hline
\end{tabular}

Table 12. Summary of Homogeneity Test Analys is of Civics Learning Outcomes of Students with High Learning Motivation and Low Learning Motivation

$\begin{array}{llll}\text { Sample Group } & F_{\text {hitung }} & F_{\text {tabel }} & \text { Informatio }\end{array}$

n

\begin{tabular}{lccccc}
\hline $\begin{array}{l}\text { Result learning Civics students who have high } \\
\text { learning motivation and low learning } \\
\text { motivation }\end{array}$ & & & & & Homogeneo \\
\end{tabular}


Table 13. The Summary of the Analysis of the Interaction Homogeneity Test between Learning Models and Learning Motivation on Students' Civics Learning Outcomes

\section{$\begin{array}{llll}\text { Sample Group } & X_{\text {hitung }}^{2} & X_{\text {tabel }}^{2} & \text { Informatio }\end{array}$}

n

$\begin{aligned} & \text { Results of the Interaction Between the learning } \\ & \text { model and learning motivation on student }\end{aligned}$
Civics learning outcomes

The homogeneity test of the interaction between learning models and learning motivation on student civics learning outcomes is used by the Bartlett formula. Based on the calculation of the Bartlett formula, the price is obtained $\chi^{2}$ count $=0.352$ while the price $\chi^{2}$ table $(\alpha=0.05,3)=7.82$. Based on this data, it can be seen that the price $\chi^{2}$ count $<\chi^{2}$ table. Thus it can be concluded that the data comes from homogeneo us variances.

Table 14. Summary of Data Calculation Results Descriptive Analysis

\begin{tabular}{cclll}
\hline \multirow{2}{*}{ Summary } & of Data & \multicolumn{2}{c}{ Learning model } & \multicolumn{1}{c}{ total } \\
\cline { 3 - 4 } & & \multicolumn{1}{c}{ Scramble } & Expository & \\
\hline Motivation & High & $\mathrm{N}=12$ & $\mathrm{~N}=11$ & $\mathrm{~N}=23$ \\
to learn & & $\sum X=1015$ & $\sum X=855$ & $\sum X=1870$ \\
& & $\sum X^{2}=86825$ & $\sum X^{2}=67675$ & $\sum X^{2}=154500$ \\
& & $\bar{X}=84.58$ & $\bar{X}=77.73$ & $\bar{X}=81.30$ \\
\cline { 3 - 4 } & Low & $\mathrm{N}=10$ & $\mathrm{~N}=11$ & $\mathrm{~N}=21$ \\
& & $\sum X=840$ & $\sum X=700$ & $\sum X=1540$ \\
& & $\sum X^{2}=71400$ & $\sum X^{2}=45450$ & $\sum X^{2}=116850$ \\
& & $\bar{X}=84.00$ & $\bar{X}=63.64$ & $\bar{X}=73.33$ \\
\hline & Total & $\mathrm{N}=22$ & $\mathrm{~N}=22$ & $\mathrm{~N}=44$ \\
& & $\sum X=1855$ & $\sum X=1555$ & $\sum X=3410$ \\
& & $\sum X^{2}=158225$ & $\sum X^{2}=113125$ & $\sum X^{2}=271350$ \\
& & $\bar{X}=84.32$ & $\bar{X}=70.68$ & $\bar{X}=77.50$ \\
\hline
\end{tabular}

Table 15. Summary of $2 \times 2$ Factorial ANAVA Calculation Results

\begin{tabular}{|c|c|c|c|c|c|c|}
\hline $\begin{array}{c}\text { Source of } \\
\text { Variance }\end{array}$ & JK & Dk & RJK & Fcount & Ftable & Information \\
\cline { 1 - 2 } $\begin{array}{c}\text { Between } \\
\text { Columns }\end{array}$ & 2045.45 & 1 & 697.46 & 7,266 & & Significant \\
\hline Between Lines & 697.46 & 1 & 2045.45 & 21,309 & \multirow{2}{*}{4.08} & Significant \\
\hline Interaction & 396.44 & 1 & 396.44 & 4,130 & & Significant \\
\hline Error (Error) & 3935.64 & 41 & 95.99 & - & & \\
\hline TOTAL & 7075.00 & 44 & - & - & & \\
\hline
\end{tabular}

Based on the summary above, the hypothesis testing is detailed as follows:

\subsection{First Hypothesis}

The first hypothesis testing is: there is the influence of the scramble learning model taught to the fifth grade students of SD Negeri 066045 Medan Helvetia on the subject of 
Freedom to Organize is higher than students who are taught using the expository model. The statistical hypothesis is:

Ho: $\mu \mathrm{A} 1 \mathrm{~B} 1=\mathrm{A} 1 \mathrm{~B} 2 \mu$

Ha: $\mu$ A1B1> A1B2 $\mu$

From the results of data analysis, it was found that the average Civics learning outcomes of students were taught using scramble learning model amounted to 84.32 and the average Civics learning outcomes of students who were taught using the expository model of 70.68. Based on Anava calculations obtained F count 7.266 while the F table value is 4.08 so that Ho is rejected. Thus it can be concluded that there isthe influence of the scramble learning model taught to grade V SD Negeri students 101766 Bandar Setia on the subject of freedom of organization higher than students who are taught with the expository model proven truth.

\subsection{Second Hypothesis}

The second hypothesis testing is: There is an effect of scramble and expository learning models with high learning motivation and low learning motivation on learning outcomes of fifth grade students of SD Negeri101766 Bandar Setia on the subject of Freedom of Organization. The statistical hypothesis is:

Ho: $\mu \mathrm{B} 1 \mathrm{~A} 1=\mathrm{B} 2 \mathrm{~B} 2 \mu$

Ha: $\mu \mathrm{B} 1 \mathrm{~A} 1>\mathrm{B} 2 \mathrm{~B} 2 \mu$

From the results of data analysis, it was found that the average Civics learning outcomes of students who had high learning motivation was 81.30 and the average Civics learning outcomes of students who had low learning motivation was 73.30. Based on the ANOVA calculation, it is obtained that the F count is 21.309 while the $\mathrm{F}$ table value is 4.08 for $\mathrm{dk}(1 ; 41)$ and the real level is $5 \%$, it turns out that the F count is $21.309>$ Ftable 4.08 so that $\mathrm{H} 0$ is rejected. Thus it can be concluded that there isthe influence of Scrambel and Expository learning models with high learning motivation and low learning motivation on learning outcomes of fifth grade students of SD Negeri 101766 Bandar Setia on the subject of Freedom of Organization proven truth.

\subsection{Third Hypothesis}

Testing the third hypothesis, namely: there is the interaction between the Scramble Learning Model and the expository with student learning motivation towards the Civics Learning Outcomes of Class V SD Negeri Students 101766 Bandar Setia on the subject of Freedom of Organization. The statistical hypothesis is:

Ho: $\mathrm{A}><\mathrm{B}=0$

Ha: $\mathrm{A}><\mathrm{B} \neq 0$

Based on data analysis, it was found the average value Civics learning outcomes of students who have high learning motivation are taught with the Scramble learning model amounted to 84.58 and on average Civics learning outcomes of students who have low learning motivation are taught with the Scramble learning model amounting to 84.00. then the average student learning outcomeswho have high learning motivation which is taught with the expository learning modelamounted to 77.73 and the average student learning outcomes who have low learning motivation taught by the expository learning model amounting to 63.64 .

Based on the Anava calculation, it is obtained F count 4,130 while $F$ table 4.08 for $\mathrm{dk}(1 ; 41)$ with a real level of $5 \%$, it turns out that the value of $\mathrm{F}$ counts $4,130>\mathrm{F}$ table 4.08 so that Ho is rejected. Thus it can be concluded that there isthe interaction between the Scramble Learning Model and Student's Motivation on Learning Outcomes of Civics 
Class V SD Negeri Students 101766 Bandar Setia on the subject of Freedom of Organizationproven truth. Complete calculations can be seen in Appendix 14.Following this interaction can be presented in Figure 9.

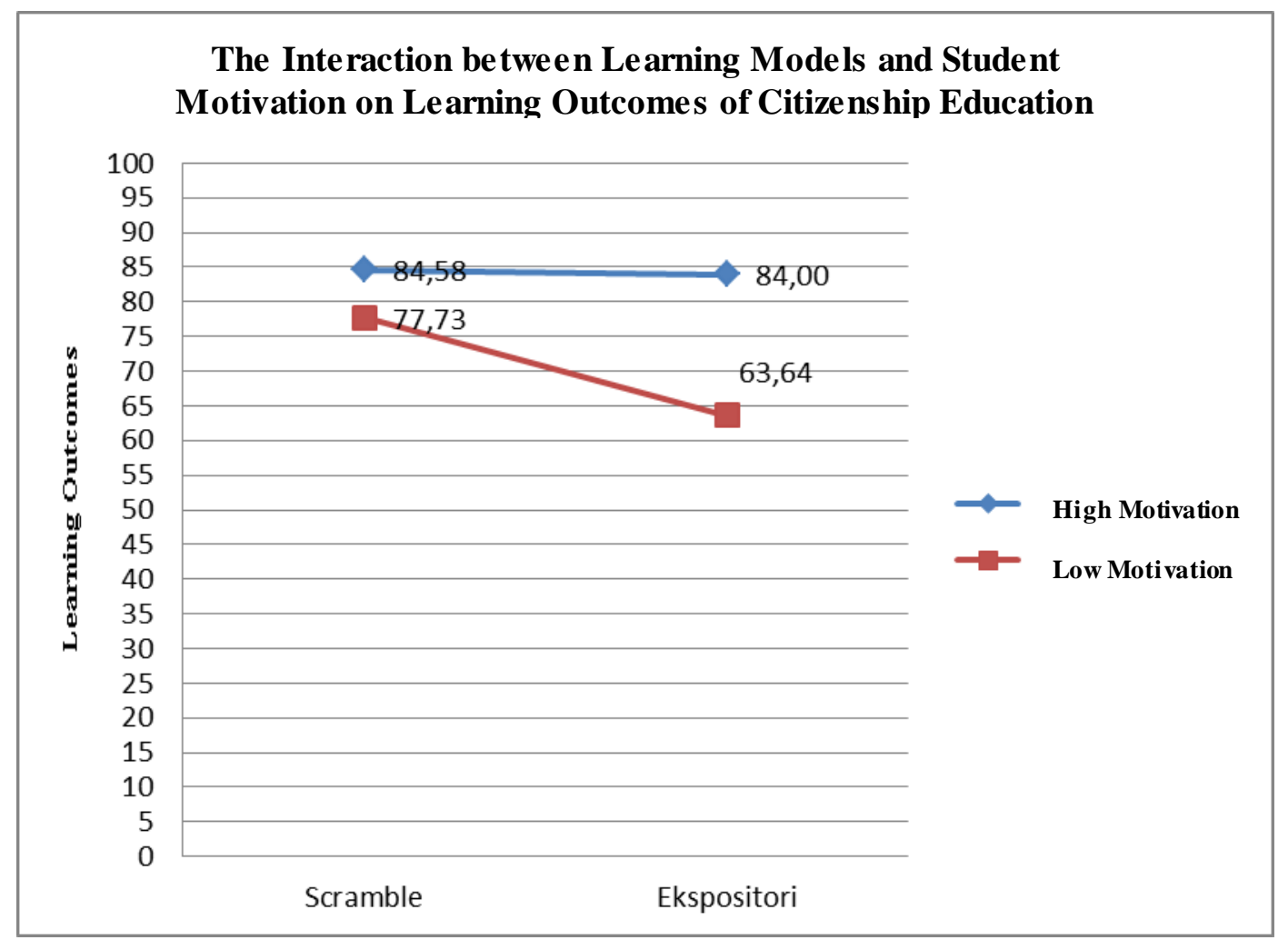

Figure 9. The Interaction Between Learning Models and Learning Motivation Against Student Civics Learning Outcomes

Table 16. Summary of Advanced Tests

\begin{tabular}{cccc}
\hline No. & Group & \multicolumn{2}{c}{ Scheefe test } \\
& & $2.81 \mathrm{ts}$ & $\mathrm{Ft}=0.05$ \\
\hline 1 & A1B1 with A2B1 & $26.23 *$ & 2.94 \\
2 & A1B1 with A2B2 & $0.02 \mathrm{ts}$ & 2.94 \\
3 & A1B1 with A1B2 & $2,15 \mathrm{ts}$ & 3.10 \\
4 & A1B2 with A2B1 & $22.63 *$ & 3.14 \\
5 & A1B2 with A2B2 & $11.38 *$ & 3.14 \\
6 & A2B1 with A2B2 & & 2.98 \\
\hline
\end{tabular}

Information:

* $\quad=$ Significant

ts $\quad=$ Not significant

A1 =Scramble learning model

A2 $=$ Expository learning model

B1 = High learning motivation

B2 =Low learning motivation

A1B1 =Learning outcomes of students who have high learning motivation using the Scramble learning model 
A1B2 = Student learning outcomes are have low learning by using the Scramble learning model

A2B1 = learning outcomes of students who have high learning motivation using the expository learning model

A2B2 = Learning outcomes of students who have low learning motivation using the expository learning model

\section{Conclusion}

Based on the results of hypothesis testing as described, this study concludes that:

1. Student Civics learning outcomes with the Scramble learning model are higher than the Expository learning model. Students who are taught using the Scramble learning model are higher than the Expository learning model in the same subject matter, namely the average learning outcomes obtained using the scramble learning model are 84.32 higher than the learning outcomes using the expository learning model of 70.68 .

2. The learning outcomes of students who have high learning motivation are better than those of students who have low learning motivation. Students who have high learning motivation get better learning outcomes than students who have low learning motivation in the same subject matter. The average learning outcome of students who have high learning motivation is 81.30 higher than the average score of students who have low learning motivation 73.30.

3. There is an interaction between the Scramble learning model and learning motivation in influencing Civics learning outcomes. For students who have high learning motivation will be more effective in improving Civics learning outcomes if they use the Scramble cooperative learning model, while for students who have low learning motivation it is more effective in improving PPKN learning outcomes using the Expository learning model.

\section{References}

Afzal, Hasan. 2010. A study Of University Students Motivation And Its Relationship With Their Academic Performance : Internatinal Journal Of Business and Management, Volume 5, Nomor 4, Halaman 132

Ahmad, Rustam. 2016. Improving the results of math learning through scramble cooperative model with the approach of contextual teaching and learning model. Jurnal of mathemathic aducation, Volume 1, Nomor 1, Halaman 7-14

Ariyanto. 2016. Peningkatan hasil belajar IPA Materi kenampakan rupa bumi menggunakan model scramble. Jurnal Profesi pendidikan dasar, Volume 3, Nomor 2, Halaman 134-140

Arikunto, Suharsimi. 2010. Peneltian Tindakan Kelas. Jakarta: Bumi Aksara

BSNP. 2006. Permendiknas No.22 Tahun 2006,Tentang Standar Isi Untuk Satuan Pendidikan Dasar dan Menengah. Jakarta : Depdiknas

Diani. R. 2016. The Best Of Effect Size Scramble Learning Model With Video Learning Media Towards Students Learning Results On Physics Of Class X MAN 1 Pesisir Barat : Jurnal Ilmiah Pendidikan Fisika, Volume 5, Nomor 2, Halaman 129

Dewi, Rosmala, 2010. Penelitian Tindakan Kelas. Medan: Pasca Sarjana Unimed

Djamarah, 2000. Psikologi Belajar. Jakarta : Rineka Cipta. 
Gagne, R.M, Briggs \& Wager (1992). Principles of instructional design. Second edition. New York : Holt, Rinehart and Winston.

Hamalik, Oemar. (2011). Proses Belajar Mengajar. Jakarta: Bumi Aksara Hamalik, Oemar. (2013). Kurikulum dan Pembelajaran, Jakarta: Bumi Aksara

Hamalik, Oemar. (2010). Proses Belajar Mengajar. Jakarta : Bumi Aksara

Hamdani. (2011). Strategi Belajar Mengajar, Bandung : Pustaka Setia

Istarani. (2011). 58 Model Pembelajaran Inovatif. Medan: Media Persada

Isnawati, Nina. (2012). Pengaruh Perhatian Orang Tua dan Motivasi Belajar Siswa Terhadap Prestasi Belajar Akutansi Pada Kompetensi Mengelola Dokumen Transaksi Siswa Kelas X SMK Cokrominoto : Journal Pendidikan Indonesia, Volume 10, Nomor 1, Halaman 79

Joyce,B,Weil,M,Calhoun. (2009). Model Of Teaching. Jakarta : Pustaka Pelajar

Kumar, Kiran. (2010). Efficient Digital Encryption Al Gorithm Based On Matrix Scrambling Technique: Internasional Journal Of Network Security \& Its Application, Volume 2, Nomor 4, Halaman 98.

Komalasari, Kokom. (2010). Pembelajaran kontekstual konsep dan aplikasi. Bandung : Refika Aditama

Magdalena, Maria. (2011). Effective civic education : an educational effectiveness model for explaining students' civic knowledge. Journal School effectiveness and school improvement, Volume 22, Nomor 3, Halaman 313-333.

Muhibbinsyah. (2010). Psikologi Pendidikan. Bandung :Remaja Roskadarya.

Munawaroh, Lailatul. (2015). Meningkatkan Pembelajaran dengan cara menulis. Jurnal Pendidikan Biologi Indonesia, Volume 1, Nomor 3, Halaman 263-273 (ISSN: 2442$3750)$.

Nidawati. (2013). Belajar dalam perspektif psikologi dan agama. Jurnal pionir. Volume 1, Nomor 1, Halaman 13-28.

Purwanto. (2011). Hasil Belajar. Jakarta: Bumi Aksara.

Raehang. (2014). Pembelajaran Aktif Sebagai Induk Pembelajaran Kooperatif. Jurnal AlTa'dib, Volume. 7, Nomor 1, Halaman 151.

Sanjaya, Wina. (2010). Strategi Pembelajaran Berorientasi Standar Proses Pendidikan. Jakarta : Prenada Media Group.

Sadirman. (2011). Interaksi \& Motivasi Belajar Mengajar. Jakarta : Rajawali Press.

Setiawan, Deny. (2016). Kapita Selekta Kewarganegaraan, Medan : Larispa Indonesia.

Setiawan, Deny. (2014). Kapita Selekta Kewarganegaraan, Medan : Larispa Indonesia.

Simanjuntak, L., Sriadhi, and Saragi, D. (2020). The Effect of Project Based Learning Models and Learning Motivation on Civics Learning Results in 4th Grade Primary School 106163 Percut Sei Tuan. Budapest International Research and Critics in Linguistics and Education (BirLE) Journal Vol 3 (3): 1509-1520.

Slameto. (2010). Belajar dan Faktor- Faktor yang Mempengaruhinya. Jakarta: Rhineka Cipta.

Sudjana. Nana. (2002). Metoda Statistika. Bandung: Tarsito.

Sudjana. Nana. (2009). Metoda Statistika. Bandung: Tarsito.

Sudjana. Nana. (2010). Penilaian Hasil Proses Belajar Mengajar. Bandung: Remaja Rosdakarya.

Sunhaji. (2014). Konsep Manajemen Kelas dan Implikasinya dalam Pembelajaran. Jurnal Kependidikan, Volume II, Nomor 2, Halaman 32.

Sumarno, Normalina. (2015). Motivasi dan hasil belajar siswa dalam pembelajaran matematika dengan menggunakan model pembelajaran kooperatif tipe Scramble di 
SMP: Jurnal Pendidikan Matematika, Volume 3, Nomor 1 : Universitas Lambung Mangkurat.

Sukmadinata, Nana Syaodih. (2011). Metode Penelitian Pendidikan. Bandung : Remaja Rosda Karya

Suyatno. (2009). Menjelajah Pembelajaran Inovatif. Jawa Timur : Masmedia Buana Pustaka.

Trianto. (2011). Mendesain Model Pembelajaran Inovatif-Progresif, Jakarta : Kencana Prenada Media.

Wahidmurni, Alifin Mustikawan, dan Ali Ridho. (2010). Evaluasi Pembelajaran : Kompetensi dan Praktik. Yogyakarta : Nuha Letera.

Widiantari, Widiana. (2009). Pengaruh model pembelajaran Scramble berbantuan Media video terhadap hasil belajar IPA siswa kelas IV SD GUGUS V Kecamatan buleleng : Tesis IPA Universitas Pendidikan Ganesha Singaraja.

Winataputra, U. (2008). Materi dan Pembelajaran PKn di SD. Jakarta: Universitas Terbuka. 